\title{
Remembering the migrant identity: a comparative study of Les pieds sales, by Edem Awumey and $R u$, by Kim Thúy
}

According to Daniel Chartier, "migrant writing" unlike ethnic literature, immigration or immigrant literature can be defined thematically by hybridity and by its frequent use of autobiography (Chartier, 2002). Dictionnaire des écrivains émigrés au Québec 1800-1999, Nota Bene 2003. The genre of «migrant literature» refers to the literature from authors that are between two cultures and focus on the travel, the odyssée. The immigrant literature is a genre from immigrant writers who settle in another country whereas the ethnic literature explores subcultures. In this way, Literature can be seen as a composition of cultural fragments. It adjusts heterogeneous cultural fragments in order to produce literary emotions. As a matter of fact, the style is a pure cultural production where writers give a feeling of this cultural fragmentation.

The concept of migrant literature appears in the Canadian context during the $1980 \mathrm{~s}$. It refers to the production of writers who, after immigrating to Canada, decided to settle in the province of Quebec - and to write within the framework of the province's literary institutions. Some representants of such migrant literature are for instance Ying Chen (born in Shanghaï in 1961), Felicia Mihaili (born in Bucarest in 1967) and Wajdi Mouawad (born in Lebanon). It is a trend that mixes autobiography fragments with migration experiences. We would like to analyze here this experience by focusing on two writers, Kim Thúy and Edem Awumey. Literature offers a new horizon for those migrant writers, as it gives the possibility to question the meaning or the meaningless world in which we live. Kim Thúy and Edem Awumey have written two novels that illustrate this literary genre, Les pieds sales (Awumey, 2009), and Ru (Thúy, 2009). The notion of world is taken from phenomenology, whereby world is a system of references, or signs that have a meaning for a group of people. The Migrant writing presents a clash of references where different meanings come from different worlds. There is a sense of waylessness pervading this writing (Fawkner, 1997, 87). Our hypothesis is that this migrant literature is a style related to the recollection of fragments of world. The fictional characters try to redefine a coherent world while travelling.

There is an old word in French for re-membering, which is la remembrance, which exists in English too, remembrance. $\dot{A}$ la recherche $d u$ temps perdu by Proust is translated as Remembrance of things past. Remembrer is a synonym for se souvenir (remomari). In La Chanson de Roland, it is written: "Repairet lui vigur e remembrance " / la force et la mémoire lui reviennent - strength and memory come back to him. Pierre Nora, the French historian, defines a "lieu de mémoire" (a site of memory). A site of memory is a relation between memory and history in terms of symbolic rituals. In our societies, the logic of commemoration emphasizes the necessity to have a collective link between the members. In this way, a process of memorizing (remembering) and a structuring process (recollecting the pieces) are both linked to the idea of "re-membering". Remembering does not mean reproducing, or duplicating time, but re-structuring time, restructuring a story and building up a new identity through words. The process of memorizing (remembering) and a structuring process (recollecting the pieces) are both 
linked to the idea of " re-membering". In both novels, we find this re-membering process at the very heart of the writing process.

\section{Comparing Biographies}

Biographies have a role in the structuration of literary identities. The two narratives are absolutely not biographical. There are no echoes of the lives of the authors as both of them worked on testimonies. Indeed, their own biographies gave them an empathic understanding of the migrant experience. This is only in this way their biography should be referred to. Kim Thúy was born in 1968 in Saïgon, and is a Canadian writer from Quebec, whose debut novel $R u$ won the Governor General's award for French language fiction in 2010. Like her story's narrator, Kim Thúy and her family fled South Vietnam as boat people and settled in Montreal in Canada. She comes from a wealthy, well-educated family in Saigon. With the take-over of the city by the Communists, life became too difficult and her parents decided to escape. Their escape by boat took them to a refugee camp in Malaysia, a squalid overcrowded place where they stayed for four months before being able to get to Quebec and to a totally new life, a new language and new challenges. As an adult woman, she returns to Vietnam and the return to the old country is shadowed by the past. Kim Thúy has written two other novels: $\grave{A}$ toi, interviews with Pascal Janovjak (2011), and Man (2013).

Edem Awumey was born in Lomé (Togo) in 1975. He now lives near Ottawa in Canada. His first novel, Port-Mélo (2006), received le Grand prix littéraire de l'Afrique noire, and le Grand prix littéraire de l'Afrique noire. His second novel, Les Pieds sales, was long-listed for the Goncourt in 2009. His other publications are Rose deluge, published in 2011 and Explication de la nuit, published in $2013^{1}$. In 2011, he dealt with the notion of space and presented it in the following terms:

"Well, I must say that 's one among the smaller shocks I experienced when I arrived there. I think that spaces are less definite there than here for instance. You know, Paris is really keeping with market principles. It is very expensive to find a place to live in Paris intra muros. An appartment is sold by the square meter, so those who have the lowest salaries are outside in the periphery". (Awumey, Premat, 2011)

In this quote, he shows that it was easier for an immigrant to live in the centre of a city, such as Gatineau, than in the centre of a metropolitan area. Big cities are places where there is a fight to live in the centre. The centres preserve the history of the city, but at the same time they illustrate the discrepancies between social groups, and especially between migrants and those who have roots in the cities. Edem Awumey deals with the use of the word "Africas" in his work..

" It is true that I often refer to Africas in my books because for me Africa is plural. But I mistrust artificial borders too. I was born on the West coast and it is well known that there are

\footnotetext{
${ }^{1}$ His other publications are Rose deluge, published in 2011 and Explication de la nuit, published in 2013. His books are translated into English ${ }^{1}$. He was invited to Göteborgs Bookfair in 2010 which had "Africa" as main theme. We had an interview with him about his work during his stay in Göteborg.
} 
very strong cultural tights between Togo, Benin and Ghana"2 (Awumey, Premat, 2011).

According to Awumey, we can find the same languages from one or another side of the borders of these countries but their differences do also exist. He condemns the artificial colonial borders and this is why he refers to Africa in terms of cities such as Bobo-Dioulasso, Ouagadougou, Lomé or Accra. In the work of Awumey, Africa does not exist as a continent; Africas exist as a plurality of spaces.

The city is a real literary space where the connections are predominant even though these connections can result in a cultural clash. The characters in these novels move in the cities: they meet, they share the same migrant experience, as the cities are structured in the same way. The psychological dimension of the characters is not important, since they are fragments of different worlds who can connect to each other by rebuilding the past. As Ariel Dorfman wrote, « from the beginning of history, migrants have wavered between extremes that promise to resolve and even abolish this fragmented anguished condition »(Dorfman, 2009). The difference between Kim Thúy and Edem Awumey is that Kim Thúy directly translates her experience into a narrative. It is a fictional narrative based on a cultural translation. This is why the reader finds in $R u$ a reflection about migration and languages. Kim Thúy is a refugee, Edem Awumey a writer from Togo who settled in Canada after having lived in Europe. Both belong to the same generation of migrant writers. Kim Thúy is a bilingual author, who speaks Vietnamese and translates some expressions and words into French. She is in the overlap of languages; in other words, she analyses the cultural perception of words in French.

The narrator of $R u$ is like a translating consciousness. He is between two worlds, trying to find a reference in the other language, which is not always possible. The narrator is like a vagrant watcher. A vagrant is an English word that does not have any translation in French. According to the Oxford Dictionary, a vagrant is « a person without a settled home or regular work who wanders from place to place and lives by begging » ${ }^{3}$. It is a synonym for a «wanderer $»$. In this perspective, both novels remind the pure experience of wandering that exists in the movie of Wim Wenders, Paris-Texas (Wenders, 1984). The movie starts with a character who just walks without any definite goal. He wanders, he does not remember the origin of the travel, but he goes on. In $R u$, the character is compelled to move, but at the same time, the destination remains unclear as the narrator focuses on small details instead of the whole frame. In Dirty feet, the reader meets wandering characters who lost the purpose of their travel. They appear as vagrant characters.

The dictionary refers to the birds and their experience of what we can call vagrancy: « A bird that has strayed or been blown from its usual range or migratory route $»^{4}$. The migration experience is an attempt of readjusting the route; in order to find out the trajectory, where the

\footnotetext{
${ }^{2}$ «C'est vrai que bien souvent dans mes livres je parle des Afriques parce que l'Afrique pour moi est plurielle. Mais je me méfie aussi des frontières artificielles. Je suis né sur la côte Ouest et on sait très bien qu'entre le Togo, le Bénin et le Ghana, il y a des liens très forts entre les cultures. On va retrouver les mêmes cultures, les mêmes langues parfois d'un côté ou de l'autre des frontières. Mais cela n'enlève pas à ces pays leurs spécificités, leurs différences. Mais je me méfie encore une fois de ces frontières coloniales artificielles et je parle souvent de l'Afrique en termes de villes. J'évoque Bobo-Dioulasso, Ouagadougou, Lomé ou Accra sans avoir besoin de préciser que quand je dis Bobo on est au Burkina-Faso » (Awumey, Premat, 2011)

${ }^{3}$ http://www.oxforddictionaries.com/definition/english/vagrant [Last visit: 20 May 2015].

${ }^{4}$ http://www.oxforddictionaries.com/definition/english/vagrant [Last visit: 20 May 2015].
} 
narrators have to balance fragments of worlds that means two different experiences that have boundaries. Literature translates a real experience of migration. Both novels are the reorganization of fragmented worlds. We can refer to the concept of Martin Heidegger In-derWelt-sein when we read the novel and the experience of being in a new world. According to Fawkner, « the technical, non-common sensical term In-der-Welt-sein was created in order to get away from the common understanding of being, of world, and of being in the world $»$ (Fawkner, 1997, 40). Migration is useful to get rid of the idea of roots (Ab-Grund), but at the same time the characters of Dirty Feet did not discover a new world, since they are rootless. In that sense, both novels deal with a pure phenomenological experience of wandering without starting point nor arrival.

\section{"Re-Membering" and the Limbs}

Les pieds sales / dirty feet is the name given to Askia's family who were condemned to a nomadic life, unable to settle long enough to rest and clean their feet. Feet represent a symbol of mobility, the mobility of Africans trying to get to Europe. "There was one, Tété-Michel Kpomassie, who had gone even farther, towards Greenland and the lands of the Inuit back in the seventies, his black feet sinking into the powdered snow up to the intangible limits of his curiosity while the compact people of the polar latitudes watched in amusement" (Awumey, 2009: 21). Tété-Michel Kpomassie is a writer and adventurer from Togo. He travelled in the North and in Greenland, he becomes the symbol for the nomadic quest. He explored the limits of the world. In the quote, we feel the contrast in the colors between the black feet and the snow. The encounter between people coming from opposite worlds is enlightened in the novel. The amusement of the "compact people" (Inuit) echoes the scientific curiosity of Tété-Michel Kpomassie. Dirty feet is a short, dense novel which consists of 43 chapters and a main protagonist Askia " he" - external focal point. Askia arrives in Paris (2005) as the bodyguard of an African diplomat (he has been an executioner too), takes the opportunity to disappear into the city of light. He works as a taxi driver and roams the streets of Paris. In the early seventies, Askia's father, Sidi Ben Sylla Mohammed, left his family to get to Paris. Now, Askia, while driving his cab, is searching for some sign of his missing father. He likens himself to the son of Odysseus " some obscure, obsessed Telemachus" (Awumey, 2009), hidden from others in his taxi. He lives in a shabby room on the outskirts of Paris. One night, he drives a young woman, Olia, a Bulgarian fashion photographer, who claims that she has photographed Askias' father, and offers to help locate the missing man, the man with a white turban. Askia will move along like his ancestors in Sahel called " the dirty feet": " He thought their departure had been because of that rain and the earth dying under their feet. He recalled those days spent crossing other arid lands, ravaged plains where a few souls hung on, resigned or reckless, full of hope or outright scorn (Awumey, 2009).

The "earth dying" under the feet is typical for the absence of a world. The world, understood as a physical relation, is absent, and the characters have to flee the past, but at the same time they have to recreate a new world. It is in a sense something different from what the philosopher Husserl writes about the Earth that does not move (Husserl, 1940, 313). Husserl made a comparison between the scientific truth (the Earth moves) and the phenomenological experience of the bodies (our bodies do not feel that the Earth moves). The Earth is a support for 
our bodies and for our movement. There is a dialectics in the text between the effects of uprooting and rerooting the relations between the characters. The reader has to collect the references in order to follow up the story.

Olia and Askia will indirectly confront some memories through photography. Photography acts as a way of structuring memory, by taking pictures for a better understanding and explanation of what has happened; the juxtaposition of collages, the balance between light and dark colors refer to a technique similar to Chris Marker's movie Level 5 (1996), when he uses a voice to work with digital pieces of archives about what happened in Okinawa during the Second World War (Lupton, 2005). The reader knows that something horrible has happened, and this is why the rerooting process is impossible. He collects some pictures of the character to figure out who the character is. The reader always tries to know the role of the characters. In Dirty Feet, this quest is more and more difficult. The chapters do not lead to anything. We find here the difference between what Heidegger calls Geschick and Geschichte. We cannot know the origin of the characters, even though they took part in different reprehensible actions. "By flattening Geschick into historiography, and by flattening being into existence, humanity ceases to have a dwelling. There is nowhere for being to take place" (Fawkner, 1997, 77). We have this feeling in the reading of Dirty Feet. The characters wander and wonder where they are, the end is not clear and the reader has no clues about the origin. Did a genocide or a mass-murder happen? The reader wonders what happened before the travel of the characters.

In $R u$, the narrator recollects some very specific feelings. The title $R u$ has to be explained. $R u$ means in French a brook, a rivulet (in another register a flow of water, blood, tears). In Vietnamese, the word "ru" means a lullaby. $R u$ is a book that translates the experience of migrants in extreme conditions. They do not expect anything about their destination, they are just survivors. The novel contains about 100 vignettes without numbers, strung together to tell us the narrator's journey to Canada, intern focal point " I". In $R u$, a woman wanders between different memories: Saigon, communism, life in a refugee camp, the first winter in Quebec: "The small bulb hanging from a wire attached to a rusty nail spread a feeble, unchanging light. Deep inside the boat there was no distinction between day and night. The constant illumination protected us from the vastness of the sea and the sky around us. The people sitting on deck told us there was no boundary between the blue of the sky and the blue of the sea. No one knew if we were heading for the heavens or plunging into the water's depths. Heaven and hell embraced in the belly of our boat" (Sule, Premat, 2011). The boat journey comes again later on in the narrative when the narrator is in the camp. The narrator is a woman. She loses her sandal in the latrins and describes how it floats like a boat. She goes bare foot afterwards for many days, trudging the mud full of worms. The mud is a recurrent motive in the book, and can be seen as a metaphor for oblivion or Ab-grund in the Heideggerian sense. The mud is like a magma of indistinctive and mixed things, it is a rootless experience. There is no fixity, the mud illustrates the chaotic experience of migration. The boat is a very restricted space where the narrator does not any free movement. The narrator and the reader find it difficult to remember all these impressions. As Fawkner writes, "the mastery of way (road, path, route, track) over ground (Grund) occurs for supernihilist man as mastery of step over presence. Footed man steps over presence, across it, past it. He passes" (Fawkner, 1997, 87). In $R u$, the narrative deals with characters without names, who are 
anonymous: "Durant nos premières nuits de réfugiés en Malaisie, nous dormions directement sur la terre rouge, sans plancher" (Thúy, 2009, 24).

"We spent our first nights in Malaysia sleeping directly on the red earth, without any floor"

The experience of migration is seen as a trip without ground. The "red mud" is synonymous for the mixture of elements. The color of red the color red is remembered as the fixation of this trip: "La Croix-Rouge avait construit des camps de réfugiés dans les pays voisins du Vietnam pour accueillir les boat people, ceux qui avaient survécu au voyage en mer. Les autres, qui avaient coulé pendant la traverse, n'avaient pas de nom. Ils sont morts anonymes" (Thúy, 2009, 24).

"The Red Cross had built refugee-camps in the neighbouring countries of Vietnam to accommodate the Boat People, those who had survived to the boat-trip. The others, who had gone under during the crossing, did not have any name. They died anonymously." The migration experience is characterized by survival. The ones who survive are no longer anonymous. The name is the reference for the survival. The narrative of $R u$ gathers the members of this experience. There is a cruel selection in this trip for survival. The use of present tense "ils sont morts anonymes" illustrates a general truth. The alternance between the pluperfect and the present is striking in the quote. The present reflects a general truth that can be applied to this kind of experience. "Those who had survived the boat trip" is the group of refugees who had a chance to have a future in another world.

In $R u$, there is an unsentimental attitude to a life of extremes. In an interview carried out by the present authors with Kim Thúy, she explained that there is no equivalent to "I love you “ in Vietnamese. It is not the heart but the head that matters.

"I I can't tell you if my parents have already said I love you: I believe that it never happened and I don't think it will ever happen. But at the same time, it is so strange because the word to love is quantified, rationalized and qualified in a very specific way. We use it so rarely that might explain why we keep intellectualizing or talking about this feeling" (Sule,Premat, 2011) ${ }^{5}$. These are her words and her interpretation of the translation. Re-membering the impressions is an intellectual reconstruction. The impression is seized in an objective way. The details are really important, since they structure the narrative. There is also a fragment of the narrative which is striking when the narrator explains that she met one of her first friends thirty years after the trip: .

"I also found again my first best friend, thirty years later. She did not recognize me, neither on the phone nor in person, because she had never heard me talk, because we had never talked to each other before, because she had known me deaf and mute"(Thúy, 2009, 82).

\footnotetext{
${ }^{5}$ Françoise Sule, Christophe Premat, (2011) "Entretien avec l'écrivaine Kim Thúy", http://www.franskaspraket.eu/spip.php?article177 [Last visit: 5 February 2015]. "Je ne peux pas vous dire si mes parents ont déjà dit Je t'aime; je pense que ce n'est jamais arrivé et je ne crois pas que ça va arriver d'ici la fin. Mais en même temps, c'est tellement étrange parce que le mot aimer est quantifié, rationalisé et qualifié de façon très spécifique. Peut-être qu'on l'exprime tellement rarement qu'on passe notre temps à intellectualiser ou à en parler de cette émotion"

6 “J'ai aussi retrouvé ma première amie, trente ans plus tard. Elle ne m'a pas reconnue, ni au téléphone ni en personne, parce qu'elle ne m'avait jamais entendue parler, parce que nous n'avions jamais conversé auparavant, parce qu'elle m'avait connue sourde et muette. Elle ne se souvenait pas vraiment qu'elle avait désiré devenir
} 
The narrator never talked to her friend when she was little because her friend was mute. She was a voiceless child, but at the same time she remembered what her friend expected from life. The voice embodies the presence of somebody, it is a living link between people. The best friend is not even known, their relation was anonymous. Even the name of the narrator is not a real mark of singular identity. "My name is Nguyĕn An Tịnh and my mother's name Nguyĕn An Tĩnh” (Thúy, 2009, 12). There is just a small typographical difference between the narrator's and her mother's names. There is no real singularity, the narrator is a collective voice as the Individuals did not really exist during that migration. The details are like lights on the way, even though the narrator does not have a clear idea of the context. In that perspective, the remembrance is part of a time-process where the writers focus on specific details that are not meaningless in the migration of the characters.

\section{Re-Membering as a Time-Process}

The time process is fundamental in the remembering process. In both novels, the narrators refer to their birth. In Awumey, Askia's birth is vague "he would have to replay the scene with the dead trees, the dry brushland, and the silence that had enveloped their migration. His mother would later inform him that it had been during the terrible Sahelian harmattan of 1967. Judging from his birth certificate, dated February 12, 1962, he must have been going on five years old, just as his scattered memories led him to believe" (Awumey, 2011, 50). There is here a contrast between the certificate and the context of migration. The character has to gather different pieces of memories to understand when he was born. The "silence that enveloped their migration" shows that nothing is said about the initial trip. The characters wander; they had to flee but they have no goal. Dirty Feet has no goal, this is why the use of ellipsis is recurrent in the book: "The past. Harlem. A trip, an encounter, a man who had been a passage in her life. But Askia did not understandright away » (Awumey, 2011, 65).

The reader is confronted with a lot of nominal sentences that illustrate an implicit meaning that is not shared by the same characters at the same level. In $R u$, birth is associated with the explosion of the war. Kim Thúy states: "I came into the world during the Tet offensive, In the early days of the year of the monkey, when the long chains of firecrackers draped in front of houses 'exploded polyphonically along with the sound of machine guns." (Thúy, 2009, 11) ${ }^{7}$. Thúy was the writer's first name but this became her last name because it was too difficult to pronounce (Twit in English means idiot). Kim is thus a first name that she chose. The reader does not find last names in both novels. In $R u$, the reader finds numbers for family members (Oncle Deux, Tante huit...). The numbers depersonalize the narrator as if the last names did not have any meaning. The family links are not really important, they are meaningless in the novel. Furthermore, in $R u$, the narrator tells a story by using the indicative present. This is more a specious present in the sense of William James (Lapoujade, 1997, 41). The specious present (James, 1893, 609) means that there is a duration of the perceptions in the present. The reader

chirurgienne, alors que j'avais toujours répondu aux conseillers d'orientation de mon école secondaire que la chirurgie m'intéressait, comme elle".

${ }^{7}$ This is our translation. 
seizes the perceptions of the past in the present, the re-membering process is characterized by the use of the specious present. The reader re-members the impressions and has a present perception of the migration.

\section{Conclusion}

Dirty feet describes wanderings without a goal. There has been a trauma in the past but the protagonist finds it difficult to get over it. The novel tries to structure some parts, some pictures in order to recollect things from the past. $R u$ is based on a trauma which is the experience of the boat people. Literature is the best way of telling the impossible journey, the reader feels as a bystander during the narrative. A bystander is a witness of something that happened in the past. Re-membering is in this perspective a new way of understanding the background. If the narrative is split, the reader can reconstruct a strong meaning. The characters of both novels illustrate what the philosopher Castoriadis calls for "collectif anonyme" (Castoriadis, 1975, 433). The characters represent a collective destiny even though Dirty Feet is a narrative showing that there is no goal. Literature helps to deal with the processes of remembering. The use of specious present is all the more striking as those perceptions of the past are still present in both novels. In our sense, the remembering process is the expression of a post-traumatic style in both novels where the characters have to understand what happens after a trauma. The past is painful and the novels re-member a narrative in order to use the fragments of the past in the present. The reader does not exactly when the traumatic experience happened. There was a war, maybe a genocide. If the narrator of $R u$ flees a genocide, one of the characters of Dirty Feet seems to be involved as one of the main actors of a former genocide. Dirty Feet is full of historical dates in order to help the reader reconstruct the biographies of the characters. Remembering does not mean that everything happened in the past, it is more a style that is used to embody the migrant identity. In both novels, the narrators were compelled to flee a country. The past is not something nostalgic, it is just absurd. The question is to know how the characters can reach a new cultural identity.

\section{Works Cited}

Awumey, E. (2009). Les pieds sales. Canada: éditions du Boréal.

Awumey, E. (2011). Dirty Feet. Canada : House of Anensi Press Inc.

Awumey, E., Premat, C. (2011). "Les espaces anonymes, entre voyage et exil. Entretien avec l'écrivain Edem Awumey". Sens Public, [URL: http://www.senspublic.org/spip.php?article845]

Castoriadis, C. (1975). L'Institution imaginaire de la société. Paris: Seuil.

Chartier, D. (2002). Voix et images. La sociabilité littéraire 80. Canada: Université du Québec à Montréal.

Dorfman, A. (2009). "The wandering bigamists of language". In: Isabelle de Courtivron (ed.), Lives in Translation. New York: Macmillan: 29-37.

Fawkner, H. W. (1997). Immanence. Stockholm: Stockholm University. 
Husserl, E. (1940). Grundlegende Untersuchungen zum phänomenologischen Ursprung der Räumlichkeit der Natur [Foundational investigations of the phenomenological origin of the spatiality of nature] In M. Farber (Ed.), Philosophical essays in memory of Edmund Husserl (pp. 307-325). Cambridge, MA: Harvard University Press.

James, W. (1893). The principles of psychology. New York: H. Holt and Company.

Lapoujade, D. (1997). William James. Empirisme et pragmatisme. Paris: PUF.

Lupton,C. (2005). Chris Marker, memories of the future. London: Cromwell Press.

Thuý, K. (2009). Ru. Canada: éditions Libre Expression.

Wenders,W. (1984). Paris-Texas. Movie. 